\section{DEFORESTATION AND RURAL SOCIETY IN THE NEPALESE TERAI}

\author{
Rishikeshab Raj Regmi
}

Nepal lies between India in the south and China in the north. It is a landlocked country in the Himalayan region with a surface area of 147,181 square kilometres and with a heterogeneous population of more than 18 millions. The mountain region ranges from 5,000 to 8,000 metres in altitude, constitutes about one-third of the national territory: the hill region (1000 - to 5000 metres in altitude) containing most of the grazing land, the forest for about $45 \%$ and the rest is the fertile tropical plain area. About two-thirds of the population live in the hill and mountaineous areas which contain, only about $30 \%$ of the country's available land resources. As a result, the population pressure on the available land resource of these areas is intense and the problems of deforestation and soil erosion have a negative effect on development efforts in these areas.

The principal natural resources are the land, forest and water. Some mineral resources (e.g. lead, zinc, phospates and limestones) are known to exist but are not yet being exploited commercially. The water resource potential is very high both for irrigation and for power generation. Agriculture including animal husbandary dominates the economic activities. Industry is still in an infant stage. It is Government's policy to raise the quality of education. In the health and nutrition sector the conditions are not satisfactory. Infant mortality is very high. For centuries, Nepal was, until 1950, isolated from the rest of the world. Now we have a democratic government with a constitutional monarchy. It is hoped that the country will move ahead with new policies and programmes. In the past the green forests were considered to be the wealth of Nepal. Dwindling of such forest resources due to a number of interdependent factors like "nature and the people". Human intervention in the form of pressure on the forest resources has cleared away a massive area of forests in Nepal. This has also had a negative impact on the environment. The most observable current environmental issues and problems are deforestation, soil erosion, landslides, uncertain rainfall and the pressure of the growing population. These issues have not only created an ecological imbalance but also have given economic hardship to the people of Nepal in general. In 1964, forests covered $45 \%$ of the total land area in Nepal, whereas in 1979 only $29 \%$ remained. It is estimated by now that forest resources by 1990 s had slowed down to $25 \%$ despite the afforestation programmes carried out by the Government and various non-governmental agencies.

A current rates and causes of declining forest reserves in Nepal differ according to ecological regions: the Hills and the Terai. In the hills, collection of fuel wood and fodder, lopping and grazing, slash and burn cultivation for farm land and timber are generally considered to be the major traditional factors responsible to damage the forest. Nepal's per capita annual energy consumption -- 11 kilograms of coal equivalent -- is among the world's lowest. About $93 \%$ of all energy is consumed for cooking, heating and lighting, and of the total energy consumed for domestic use, over $92 \%$ is fuel wood. In urban areas, people are switching over to kerosine, electricity and LP gas but these options are possible for only a small fraction of the population. In rural areas, alternative sources of energy are scarcely feasible. Fuelwood substitutes for rural villages, which constitute most of Nepal's population, is becoming impossible. Crop production, livestock raising and forest form the cornerstone of nutrient inputs for crop land in Nepalese hill farming systems, originate largely from animal manure and leaf materials. Demand for fodder is probably the greatest pressure on forests. Almost every household in rural areas keeps domestic animals. The supply of forest fodder and grass to feed the livestock over the years is declining, with the result that there has been severe pressure on the remaining forests and grazing areas, leading gradually to further degradation. The supply of timber from the governmental fuelwood corporation enterprise is erratic and unreliable, and this has encouraged the private sector and individuals to engage in illicit felling of trees. The pace of deforestation has further been increased in recent years by the development activities of the Government related to road consruction, irrigation, dam building and proliferation of administration centres. In general, little amount of the timber obtained through forest clearance goes to actual developmental works, most goes for other commercial purposes. In addition to these pressures, the impact of tourism, establishment of national parks and the nature of government policies are also resulting in the rapid commercialization of timber and firewood. Deforestation in the Terai has been caused mainly by the clearing of forest land for agricultural purposes. Forest use in the Terai for agriculture was associated with the concentration of large agricultural land in the hands of a few individuals under various systems of land tenure. The state also seeks revenues from such land. Birta (state landlordism) and raiker (land granted 
to individuals as a favour for a specific job) were two major land tenure systems employed before 1957. Whatever the legal status of the forest, the state exercised little control over forest use during this period. The Government encouraged individuals (birta holders and zamindars) to convert forest land to agriculture field as a means of extending state control over territory and increasing net revenue through land taxes.

A total of 103,968 hactres of forest was cleared under the resettlement programme from 1950 to 1986 . During this same period migration from the hills to the Terai was mainly for economic reasons. Together with the several resettlement policies of the government until early 1980, the pull factors (such as the eradication of malaria in the Terai, easy access by road connections, and possibilities of employment, encouraged huge numbers of rural mountain and hill people to migrate into the Terai plain. The influx into the Terai was a result of both the government's resettlement's programmes and illegal encroachment. The construction of the East-West highway and its corridors joining the north to south belts has further given impetus to migrants to enter the Terai plains. Due to migration, land fragmentation has resulted from migration leading to shortage of agricultural area, which in turn has created insufficient food production and indebtedness, and has damaged environmental conditions and the economic situation of farm families.

In Nepal inheritance of land property passes through the male line. The existing social system of equal inheritance of land amongst all sons has created fragmentation and increased sub-division of household plots to the extent that land sizes are progressively decreased and become insufficient to provide subsistence. Because of their meagre amount of the land and small margin of economic safety, many houscholds become extremely vulnerable to indebtedness. In many cases even an illness of a family member may throw the whole houschold off balance. Similarly, the increasing pressure on cultivated land due to rapid spread of cultivation can lead to a situation whereby land prices escalate. Furthermore, demographic pressure has reduced availability of land to rent and has also reinforced higher rents for land. The reason for high demand for land ownership amongst the landless population is that it allows that population not only to grow staple crops for subsistence but also provides them much needed security by enabling them to own the plots upon which they build their houses. For these reasons, migrants having no shelter and land began clearing forest wherever possible.

Government forestry policies are also directly responsible for the degradation of forest. The nationalization of forests in 1957 has led not only to further tree clearing but also to the rapid disintegration of forest and local resource management practices. Attempts put forward since 1970 have also failed to solicit the desired level of co-operation. In the government's established national wildlife parks and reserves, litule attention has been given to the forest needs of local people. As a result, people living in areas around the reserves are often forced to over-exploit a reduced area of forest. This process of forest degradation has contributed greatly to total socio-economic costs for various ethnic groups.

Deforestation and itseffects on environment and socio-economic processes are the basic interacting elements causing harm to rural societies in Nepal. They have caused varying degrees of loss and a variety of changes which have resulted in the present socio-economic and environmental situation. Their direct effects relevent to socio-economic processes are on crop production/yield, fuelwood, fodder, timber and allied forest products and income and employment. Overall yields of almost all crops have declined in the hills for the last twenty five years caused mainly by declining soil fertility due to washing away of valuable plant nutrients and scouring of top soils. There has been the shortage of fuelwood both in the hills and Terai. Poor families are badly affected due to shortage and high price for fuelwood. Landless women and children dependent direclty on income from the forests through the collection of fruits, roots and tubers, processing of cane in the hills and the selling of wood in the Terai have vanished over the years. Furthermore, employment opportunities for landless women and children in processing of forest products have been gradually diminishing. Environmentally, the most serious impact resulting from forest degradation is the loss of cultivable soil - the most obvious cause being soil erosion. Much natural erosion occurs in Nepal because of heavy monsoons and steep terrain. Top soils, heavy mud and stones are washed away every year. It is reported that the annual top soil loss from Nepal is about 200 million cubic metres which is at the rate of $4.5 \%$ per square kilometre per day. Further, a typical hill watershed contributes a total sediment of 21 tons/ha/year which equals between one and two $\mathrm{mm}$. of soil cover per hectare per year. Debris transported by rivers from the hills and mountains is deposited downstream, changing the course of rivers and inundating fertile Terai flat land.

\section{Mechanism and Process of Deforestation}

The physiographic structure of the Terai is that it extends from east to west along the southern part of the country, adjoining some parts of the north 
Indian border with an elevation ranging from 60 to 300 metres above sea level. This belt forms a low flat land comprising about $23 \%$ of country's total land area (14 million hectares). It is characterised by its low lying and almost flat nature and fertile soil formed by the extension of Indo-Gangetic plains. It possesses a sub-tropical climate which favours cultivation of food grains. It produces abut $54 \%$ of the country's total food grains and almost of all of its cash crops including sub-tropical fruits. It sustains some $44 \%$ of the country's population (APROSC 1986). The Terai forests are dominated by hard woods (primarily Shorea robusta) and were estimated in 1986 to have covered 0.45 million hectares (MPFS, 1988)

\section{Land Tenure System}

Land tenure institutions are among the most obvious manifestation of the power relationships that directly affect rural people in Nepal. Such power relationships are inherent clearly in Nepalese social system. In primary agrarian societies, they crystalize the relations among the individual, social groups and classes in their access to land labour and hence to wealth, opportunities and power (Barraclough and Ghimire, 1990). In Nepal, various types of land tenure systems notably the Raiker, Birta, Jagir, Guthi and Kipat, have historically influenced the relationships between various ethnic groups. Raiker is a state landlordism in which the state retains full rights of its use and alienation. After the unification of Nepal (1768-69), the monarchy started granting large area of Raiker cultivated and cultivable lands. The land grants were made to the members of the royal family and nobility, civil and military officials, priests and other selected groups of the society. Its purpose was to enrich the members of the ruling classes and to assure them of the support of vested interest with a view to preserve their authority. It became a legitimate and effective tool for the exploitation of the common people, enhancing the social and economic disparities. Lands assigned as their emoluments for their services and loyalties took the form of Jagir land tenure. The beneficiaries of both Birta and Jagir land grants were entitled to collect revenue from all sources and dispense justice. Land grants made for the maintenance of and charitable institutions astemples and monasteries were then known as Guthi, Kipat was another form of land practised among Rais and Limbus who inhabit in the eastern part of Nepal. Birta holders had also set up their forest of fices in their respective forest. Birta system has a great influence on deforestation process in Terai. The emergence of Rana autocratic regime in 1846 heralded a new era in the history of Birta system in Nepal. When Junga Bahadur Rana, the first Rana primeminister, came to power by massacring all his opponent and rival nobilities in 1846, he and his successors adopted a policy of enriching the members of Rana nobility through liberal Birta grants. Mostmembers of the families of Ranas were granted Birta in Terai because of the existence of plethora of fertile land and forest resources. The Rana family autocracy lasted for 104 years, till 1950 in Nepal and plunder all the economic resources including forests. The beneficiaries of these Birta land grants had an opportunity of maximizing profits through the collection of revenues either from the cultivated land or from forest products. Collection of revenues from the cultivated land/ settlements was possible only through reclamation of forest land. The birta holders had appointed Jamindars (non official local tax collection functionary) and Subba (local tax collector) for land reclamation, establishment of new settlements and exploitation of forest products. With a few exception, hill people hesitated to go to Terai for new setulements due to fear of endemic malarial diseases. Therefore generally the people inhabiting in the hills and Terai were given the title of Jamindar, Chowdhary and Subbas. They started clearing the forests for new settlements. Such setulements would call Mouja. Moujas were under the jursdiction of a Jamindar and Subbas. These Jamindars and Subbas used to visit the birta during december to february when there was less chance of being caught by malarial disease. During their absence, their duties were performed by their Karindars, the assistants. In addition to the land reclamation and revenue collection Jamindars and Subbas were also authorised by the Birta holders to discharge the legal, judicial and administrative functions within their Moujas. Birta holders had also set up forest offices in their respective forested land area to maximize profits from timber extraction and their export to India. The expansion of rail-way lines to north India played a contributory roles in the deforestation process by facilitating timber export to India during British colonial period. This process of timber export to India by the birta holders continued until 1969, when it was formally abolished.

\section{Migration and Land Settlement}

Migration in Nepal is not a new phenomenon. During Rana regime (18461951), the hill people used to migrate to India and Burma in search of livelihood. The Rana rulers made several efforts for land settement in the Terai but failed to motivate the hill people due to the wide spread fear of malaria. Then the rulers encouraged, even Indian settlers while Nepalese migrants migrated for land and livelihood to India, Sikkim, Bhutan and Burma. But migration from the hills to Terai was never adopted as a survival strategy by the hill people despite the high population pressure on limited cultivated land in the region. But now the population of Terai has been increasing faster than of hill and mountain over the years. It is evident that the Terai accounted for only $35 \%$ of total population in 
$1952 / 54$, has increased to $44 \%$ in 1981 . The corresponding figures for the mountain and the hill declined from $65 \%$ in $1952 / 54$ to $56 \%$ in 1981 . The population of Terai increased by an average annual rate of growth of $2.9 \%$ from 1952/54 to 1981. The corresponding increase of the Terai population is attributable, interalis, to exodus of people from the hill to the Terai, after malaria was eradicated in mid 1950's with the joint collaborative efforts of HMG, USAID and WHO. After the eradication of malaria, the Terai once known as "Death valley" transformed into a principal settlement area for the hill migrants.

In general, the major push factors of migration from hills to Terai are: population pressure, insufficient land holding, dfficiency of food productions, indebtedness, deteriorating environmental conditions, natural calamities, lack of employment opportunities etc. Analogously malaria eradication, availability of land, greater availability of food, better health, education and transportation facilities, better agricultural wages are the major pull factors of hill to Terai migration.

\section{Political Liberalisation}

It is very essential to consider the political context of deforestation in Nepal Terai. After the coup d'lat of 1960, with the introduction of Panchayat system, much of the opposition to the king were from Terai where the majority of the population was of Indian origin and was influenced by Indian political culture (i.e. the multi-party system and direct franchise). In order to achieve the political integration of Terai people into the monarchy led $P$ anchayat system, the migration of hill people (who were believed to have more loyal to the monarchy and the Panchayat system) into the Terai was seen to be very crucial. For this purpose, even the Nepalese of hill origin setuled abroad wêre encouraged to return Nepal and given land to settle in Terai. There were also fear that the leaders and workers of then banned Nepali Congress exiled in India might organize opposition party across the border, which they infact did in 1962, but failed to succeed. In this context, generating support for the Panchayat system in the Terai was of great importance and urgency. Consequently, such political considerations affected the land resettlement policies. In 1970 seven ex-service men colonies were developed in the districts of Jhapa, Sunsari, Rupandehi and Banke in the Terai area with about 7,000 ex-service men's families settling there (Elder et al. 1976). Similarly various political and non-political groups were also able to acquire land through the personal decrees of the king. The king granted land to those who were serving inside the royal palace and to other political and local leaders who were loyal to him and the Panchayat system. The loyalty and the support of the military high officials and the political leaders and workers were important for creating a stable political environment. In many ways, such land grants were not much different from the earlier birta and jagir grants. Thus, these people who were considered the key to the political system by the king, were able to acquire property rights over uncultivated forest or waste land at no cost to them. All this led to the acceleration of deforestation process in Terai (Uprety, 1981). The opportunistic exploitation of timber and forest enchroachment was further intensified in the Terai after the introduction of multy-party system in May 1990. Multy-party system in Nepal was introduced by over throwing the thirty years old dictatorial partyless Panchayat system by people's movement and the interim government was entrusted with two major responsibilities: framing of a democratic constitution and holding of general election. Availing of this transitional phase of politics the forest encroachment was so intensified that the enterim government was compelled to constitute a Forest Protection Task Force. On the other hand the regressive elements who exploited the forest resources of the country for 30 years under the Panchayat system were actively involved in deforestation by creating an artificial problems of sukumbasis (squatters) in the Terai. The landless people also endeavoured to have access to a patch of land through forest clearance during this transitional phase. The deforestation by the Sukumbasi was accelerated in an organised way. The former panchas had created an organisation named "Sukumbasi Service Association" and its function was to distributeplots of lands to the landless. Thus, through this association a kind of parallel government was created to accelerate the deforestation furthermore. Later the forest protection task force visited such areas and with the joint efforts of the task force, administration and the local political groups, the so called sukumbasis were persuaded to go back to their respective places. Before the general election that was held on May 12,1991 political parties also could not antagoniz these encroachers in the forest, kecping in view of the election. The professional timber smugglers with the help of the political supporters had also then increased the timber exports in the various districts during this political transition.

\section{Public Policies and Development Programs}

In Nepal, as in many other developing third world countries, deforestation is always linked with the process of development. The process of development has immensly contributed to accelerate the rate of deforestation. In the construction of east-west highway, hundreds of hectres of forests area had been cleared along the road side and huge extraction of timber were made for use of construction of 
bridges, culverts, heating charcoal for pitching etc. And also the people were encouraged to settle in a group particularly in the road side and construct shanti towns for business and had started occupying land by clearing the remaining forest area. Community managed as well as Government managed irrigation projects have also contributed in the distruction of forests. Each year, canals are repaired and labourers pick up the forest products with undue purposes. Several thousands of tree saplings are cut for the use of dam building and canal construction.

\section{The Problem of Open Border}

To a larger extent, open border of Nepal's frontiers in the south with India is also responsible for forest destruction. People fell trees in the forest for timber extractin and export to India by ox-pull carts particularly during the night. Such timber theft is usually done in an organized way by the landlords and influential people. Timber in India is more expensive than Nepal so the smugglers are motivated to export timber to India for higher prices despite legal ban. In frontier areas curruption has become an established feature. What the smugglers need to do is that they are required to pay illegal remuneration to forest people and in the custom offices. Indian traders are always ready to buy the valuable Nepalese timber at the Nepal India border. However, at present the illegal practice of exporting to India, in terms of quantity, has declined due mainly to the decline of forest area over the decades.

\section{Livelihood System}

The basis for living of the entire households of rural people of Nepal are the natural resources and their products. Most of the family has a small house (generally small shanty shelter), small parcel of land and a couple of livestocks. Food grains vegetables and fruits are grown in their small parcel of land. Livestocks are used as a means for agriculture and ploughing. Their sale provides them for purchasing of salts, oil and clothing apperels. Timber for construction of houses and livestock shade, fuelwood for cooking, fodder for livestock, leaf litter for manure are taken from near by forests by these households. And the wild fruits, roots and tubers also are taken from the forest which are very near to their households. In general, the majority of people have this standard and this is the reality of their economic situation.

Even during last several decades when population problem was not serious, the balance between demand and supply of natural resources was maintained. Forest was abundant in ratio in comparison to population density and their demand. Since ancestors, man-forest relationship was simple and was easy to survive but now the situation is different, demand has exceeded supply.

\section{Social Consequences of Deforestation}

Environmental degradation associated with deforestation often has affected delicately maintained production and subsistence system within the Terai rural areas in Nepal. Forest depletion has led to massive soil erosion in the Terai where foot of soil has been considered as precious and is required to produce basic necessities of life such as food. Landslides and floods are very common in the mountains and the hills due to the loss of ground holding trees. Soil erosion and landslides in the hills have been the contributory factors to decrease productivity due to deposition of eroded soil, widening of the river and the stream beds in Terai, there by causing high inundation, destroying human lives, setulements, crops, livestock and other property during every monsoon.

Deforestation process has generated fuel wood, fodder and timber scarcity. The fuelwood and fodder scarcity has negatively affected the delicately maintained subsistence system of the farmers. Fuelwood is the dominant source of energy in Nepal as it meets $87 \%$ of the energy requirement and this particularly so in the absence of other alternative fuels. Not long ago fuel wood collection, in the Terai, was not a difficult task in view of time for collection and nearness to forest. Wood was abundantly available in the near by forest of the human settlements because of the low density of population and the regular regeneration of the forest biomass. Merely one hour was sufficient to collect one bundle of fuelwood. But now it takes hours to collect the same quantity of fuelwood. Fuelwood prices have gone up in the urban centres because the poor professional fuelwood sellers have to use more labour and time in the collection of fuelwood owing to the gradual disappearance of the forest resources. As the forest depletes, these poor people also have to lose their means to have their living expences through fuel weod sale. Deforestation has also resulted in the fodder scarcity. The relationship between the forest and the arable land has now been irrevocably disturbed. Land requires a net transfer of fertility from the forest by transport of leaves and grass either to the field directly or more usually as fodder to stall fed animals, when it is distributed as farmyard manure to the fields. If this transfer does not occur in sufficient quantity to maintain nutrient levels and structure in the soil, a decline in fertility occurs (Blaike et al., 1980). Now fodder collection has become a very time consuming job. And most grazing lands have disappeared. 
Therefore the fodder scarcity has resulted to the decline of livestock population and consequent decline in the income of farm families from the livestock products. Decline in livestock also means the decline in manure production needed to fertilize the field, which results in the decline of agricultural productivity. Consequently, the poorer peasants have become the victims of the vicious cycle generated by the deforestation process. Women are the principal fuelwood and fodder collectors in Nepal. Therefore, they are the most adversely affected population by the process of deforestation. With an accelerated process of deforestation, there has been the added pressure on women in collecting fuelwood and fodder and fetching water. They, in tum have become progressively over loaded and undernourished. This affects eventually to their next generation of children, because they begin life with more and more deficient in essential nutrients, thus worsening the situation further. Since the women have to spend most of their time in collecting firewood and fodder, fetching water and discharging other household affairs, the elder siblings of poor households have to take care of the younger siblings in the absence of their mothers and, are deprived of their education.

Similarly, there has been a growing scarcity of timber predominantly needed for construction purposes. Because of timber shortage in the Terai richer people have now started constructing concrete brick houses instead of constructing wooden houses which used to be built some twenty five years before. At times valuable such as sal tree (shorea robusta) was abundantly available. On other side, the poor landless people have started constructing small shanty houses/huts using soft bushes. Again, these small shanty houses are particularly unhygienic for the women who have to spend their time in their unventilated small kitchen. Poorer and landless communities are not in a position to buy good timber for building new houses. Because of the deforestation process, there has been the soaring price of timber in the urban centres. The slash-and-burn cultivation practices generally undertaken by many poor people of the indigenous communities are on the process of its disapperance owing to the reduction of the forest area. Similarly, the hunting-gathering economy of the people living on frontier lands is also going to be vanished. Forests playing significant role to the poor rural farm families in nutrient supply in areas of food scarcity and in periods of food shortages have very low potentialities of obtaining these products. Poor people collecting or gathering fruits, nuts, roots and shoots to supplement their diet have gradually been cut down. Similarly the hunting of wild animals for meat consumption particularly of forest dwelling communities has already been diminished. Likewise, women's supplementary cash income through the sale of various forest products (e.g. fruits, yam, honey, etc.) has also drastically declined. Poorer peasants of different ethnic groups are increasingly finding difficulties to extract wood for making of various farm implements needed for their agricultural activities. Thus, the livelihood systems of the poor people belonging to various socio-economic strata have been severely affected by the deforestation process. Nontheless, some social groups at the same time, have also benefitted more from deforestation at the expense of others. Urban population are getting steady and cheap food supplies grown in the heavily deforested areas of the Terai. The landed households and merchants are able to buy land in urban centres from deforested areas and from there they flourished through their business. On the other hand, the ethnic communities (e.g. Tharus, Dhimals, Rajbansis, etc.) of Terai further marginalized through the process of dispossession of their traditionally held forested land by higher and dominant castes people who migrated to Terai after malaria was supressed. More importantly, Birta holders and jagirdars of the pre-1959 and the key supporters of the Panchayat system and senior palace officials and military personnel, belonging mostly to higher castes took the maximum benefit from the large scale deforestation in the Terai. By and large, the honest and the poor population of Terai has become the victims of the deforestation and development process which affected them negatively in their livelihood system. Forestry supports agriculture and livestock, husbandry making important contributions to the farming economis. The Terai farming system is comprised of a complex arrangement of soils, water, crops, livestocks, forest and other resources within an environmental setting. The agricultural families, then manages in accordance with its preferences, capabilities and available technology. The farmers are engaged in production of crops, livestocks and non-agricultural commodities such as handicrafts and other income generating activities of the farm to supplement thcir income. But, as a whole, the process of deforestation has inversibly affected the subsistence agrarian economy of the different social groups living in the hills and Terai regions of Nepal.

Deforestation has also equally affected on the traditional livelihood system of some of the disadvantaged groups of the society (e.g., Kamis, the blacksmiths). Their traditional livelihood system is completely based on forest. In caste stratified society of Hindus, all agricultural implements such as plough share, sickle, khukuri (a traditional Nepali knife) etc, were used to be made by these blacksmiths. All agricultural households, irrespective of their ethnicity, require these implements for agricultural economies. The kamis in the process of preparing these agricultural implements, have established an aran (an 
indigenously designed furnace operated by hands to blow wind for burning fire to heat the iron) which requires tremendeous quantity of charcoal, known as gol in the common parlance. Thus, operation of an aran is not possible without charcoal. Consequently their traditional livelilood system is affected. The farmers of different ethnic groups are greatly affected because kamis are no longer be able to prepare as well as repair their agricultural implements.

\section{Social Response to Deforestation}

Due to the severe consequences of deforestation in various ecological zones and its impact on livelihood of the people there also has been growing awareness among the individuals, communities and the state. Endeavours towards the preservation of forests have been made in varying ways. Social structures of individual households, communities and in a whole state is apprehended to have changed through the development of options to cope with depleting forest resources.

\section{Individual Response}

Due to adverse effects of deforestation, various social coping mechanisms are developed at the household level just to maintain the subsistence level. Rural energy problems created due to fuelwood shortage have been solved through switching over to other substitution of fuels. As wood has become scarce, women no longer have been able to select the size and types of fuelwood they prefer. Consequently roots and shrubs previously left in the fields are cut from degraded forest. Fresh branches are also cut from healthy trees. Many indigenous communities have started burning dung-cakes due to fuelwood shortage as substitute.

One way of coping mechanism of the farmers, in the Terai, has been the reduction of the quantity of fuelwood used for cooking, heating and lighting. They have started uncooked "kudo" (a kind of gruel prepared by mixing salt, husks, etc. in the water) to feed the livestocks. Decline of fuelwood availability has also led farmers to burn agricultural residues such as maize stalks and paddy straws in the Terai.

Some middle class and rich farmers have resorted to planting trees in their own waste land or unproductive land to meet the fuel wood and fodder requirements of the households. The blacksmiths to some extent have also started planting sal trees in their waste land with the hope that they will be able to continue their aran
In urban and towns people have resorted to using kerosine and electricity for cooking purposes. Trees are planted now, even as the cash crop in many parts of Terai. The landless poor families living close to the urban areas have started to work for agricultural wages or other wage labour besides, selling the fuelwood. Some rich farmers have installed gobar gas plants in response to fuelwood shortage. The timber has become a scarce commodity so people have started to buy ready made wooden houses. The farmers are using corrugated zinc as roffing material due mainly to the shortage of thatching materials previously available in the forests. Poor people use small straws and branches for thatching purposes. In the Terai people have also devised other social responses to fodder shortage. Farmers have started feeding inferior fodders to their livestocks. They have reduced the number of lifestock and are practising stall-fed. They have started raising poultry and pigs to cope with their problem of fodder scarcity. To provide nutritional value to rural poor, traditional contribution of roots and tubers in the private land has further been increased (e.g. yam, sweet potato, taro) etc. As result of deteriorating economic condition due to agravated forest ecosystem and other natural calamities, many landless poor men seasonally or permanently migrate to the cities, development projects sites, within Nepal and to Indian cities in search of assured income and to sustain their livelihood. As poor males migrate to imporve the deteriorating household economic condition, females become the defacto heads of the households. They discharge the household duties and manage the family farms with the help of the younger children, thus, depriving the younger children from schooling. Children are compelled to look after the younger, when their mothers are away from house to collect fuelwood and fodder. What their response to this situation is to be away from education. Communal responses to ever growing deforestation is hard to find in Terai, The awareness among different social groups is creating response in protecting and planting new trees in their respective places. Community plantations has been another endeavour of the village people so as to conserve natural water resources and to generate ground grasses around the river, streams, catchment areas and in previously left pasture land. Always community participate for the common purpose.

\section{Government Response}

In order to prevent the destruction of forests, the government nationalised forests along with private forests in 1957. Until the late 1970s the government hoped that placing forests under the control of the Forest Department would ensure proper use. It provided negative effect to the people and indigenous forest management system. People, as a result, started deforesting the forest 
unprecedently. Very lately, the government realised the possibilities of forest protection through the local people by entrusting responsibilities to them for their active participation. It was in 1978 that philosophy of community forestry came into existence through the process of legislation. Two major forest categories developed under the policy of community forestry were: (1) Panchayat (village level political and administrative uni, (2) Panchayat protected forests. The village level community used to receive three fourths of forest product income (Wallace 1987). Government also made a provision to lease forests under private ownership. The leases were allowed to afforest and manage the degraded land, there by enjoyed the advantages from it. Panchayat system no longer exists and the community participation had not been so fruitfull. In April 1990 , the thirty years old dictorial Panchayat system was overthrown by the people's movement and the democratically elected the then government considered the forest destruction and encroachment illegal and took strict action. The government has set the policy of legally confiscating the excess land and has also confirmed that such land will be distributed to Sukumbasi (squatters). Also with the help of foreign aided projects, the government, for the last decade has taken steps towards the dissemination of improved stoves with the objective of minimizing the traditonal fuelwood consumption pattern. This dissemination of improved stoves has been a governmental response to deforestation. During the last few years, the government has encouraged farmer for installation of bio-gas plant, provided loan through agricultural bank with interest. But only very few farmers, who are rich, have benefitted. It is not possible for the poor farmers to afford the money as it is very costly.

With the consideration of country's physiographic structures and availability of abundant water resources and their feasibilities, govemment is trying to develop several small-scale hydro electricity projects in the different rural villages of Nepal. But due to the lack of technology, man power, and capital, this initiation has not so far been faster. The government has not been able to fulfill the demands for the majority of the Terai rural people. The supply of kerosine as fuel in the urban areas by importing from the foreign countries is also an alternative response from the government to deforestation.

\section{REFERENCES}

Acharya, M. and L. Bennet 1982

Women and the Subsistence Sector: Economic Participation and Household Decision-Making in Nepal. World Bank Staff Working Papers No. 526, Washington D.C.: The World Bank.

Adhikari, J.

"Hand over of Forest to People During Rana Period: A Case from Kaski District", (Draft manuscript). Pokhara, Nepal.

Barth, Fedrik

1980

Nomads of South Persia: The Bassari Tribe of the Khamseh Confederacy. Oslo: Universitetsforlaget.

Bennet, J. W.

1976

The Ecological Transition : Cultural Anthropology and Human Adaptation. New York : Pergamon Press.

Bennet, J.W.

1963

"Social Patterns of Forest Exploitation".J.W. Bennet and I. Ishino, Paternalismin the Japanese Economy, Minneapolis: University of Menesota Press.

Brokensha, D.W. and Riley B.

1989

Managing Natural Resources: The Local Level. Man's Role in Changing the Global Environment. New York: Academic Press.

Campbell, J.G. et al. 1987

Socio-economic Factors in Traditional Forest Use and Management : Preliminary Results from a Study of Community Forest Management of Nepal". Banko Jankari (Kathmandu). 1(4), pp. 45-54. 
Caplan, L.

1970

Land and Social Change in Nepal : A Study of Hindu Tribal Relations. London: Routledge and

Kagan Paul.

Cohen, Yehudi A. (Ed.)

Man in Adoptation: Cultural Present. (second edition) Chicago: Aldine.

Fisher, R. J.

1989

Indigenous Institutions and Organisations in the Management of Common Property Forest ResourcesinNepal. EAPI working paper. Honolulu: Eastwest Center Environment and Policy Institute.

Gaige, H. and Fedrick H.

1975

Regionalism and National Unity in Nepal. New Delhi: Vikas Publishing House Pvt. Ltd.

\section{Gilmour D.A. and Fisher R.J,}

1992 Villagers, Forests and Foresters. Kathmandu: Sahayogi Press.

Greetz, C.

1974

The Ecological Approach to Anthropology. Readings in Anthropology. Guilford, CT: Duskin annual editions.

Griffin, D.M

1988

Innocents Abroad in the Forests of Nepal: An Account of Australian Aid to Nepalese Forestry. Canberra: Anutech Pvt. Ltd.

Ives, J. D. and Msserli, B

1989
Mahat, T.B.S. et al.

$1966 / 67$

"Human Impact on Some Forests of Middle Hills of Nepal". Parts 1-4. Forestry in the Context of the Traditional Resources of the State. Mountain Research and Development.

Molner, A.

1987

Forest Conservation in Nepal : Encouraging Women's Participation. Seeds (The Population Council) 10, pp. 1-20.

Regmi, M.C.

1963

Land Tenureand Taxation in Nepal: 3 vols. Barkeley - Institute of International Studies, University of California.

Shrestha B. and Uprety, L. 1991

Social Dynamics of Deforestation in Nepal (Draft manuscript). Kathmandu.

Vayda, A.P.

1981
Environment and Cultural Behaviour: Ecological Studies in Cultural Anthropology. New York : Natural History Press. 